Article

\title{
Children's Personal Data: Discursive Legitimation Strategies of Private Residential Care Institutions on the Kenyan Coast
}

\author{
Njeri Chege \\ Institute of Education, Johannes Gutenberg University, 55099 Mainz, Germany; nchege@uni-mainz.de
}

Received: 23 May 2018; Accepted: 26 June 2018; Published: 13 July 2018

\begin{abstract}
This article looks at how charity organizations running private residential child care institutions on the Kenyan coast make use of the personal data of children in their care, as a means of securing and maintaining the support of donors from the global North. The strategy involves the online showcasing of children's profiles-individual children's photos, accompanied by their names, birth dates, annual development, and their emotion-inducing personal and/or family histories are posted on the respective organizations' websites, making them accessible to the global public. I analyze and problematize this practice, positing that while it explicitly serves fund-raising purposes and is motivated by the search for cost-effective fund-raising-oriented communication, at a more implicit level, it is equally a strategy used to discursively legitimize the organizations and their child 'rescue' activities, within the contemporary climate of deinstitutionalization. This strategy results in a violation of children's rights; has ethical implications; and is not without consequences for the concerned children's well-being.
\end{abstract}

Keywords: children; children's rights; private residential child care institutions; NGO legitimation strategies; humanitarian representations; Kenya

\section{Introduction}

Studies conducted in psychology, social work, and medicine, among other disciplines, have shown the negative impact institutional child-rearing has on children's emotional, social, cognitive, and intellectual development ${ }^{1}$. Research and press reports in numerous Southern countries have also shown that today, a large majority of children living in residential care institutions are not necessarily there because they genuinely lack parents and/or extended family. Most often their institutionalization results from interrelated factors, notably, family crises, poverty, and social and political upheavals ${ }^{2}$.

Over the years, these considerations have led to a shift in thinking as the work of child-centered international non-governmental organizations (INGOs), intergovernmental organizations, and that of medical and academic researchers, has emphasized the need to bring to an end the up-bringing of children in institutional settings. Today, numerous national governments in both the global North and South are engaged in deinstitutionalization — understood as processes through which the national child protection systems are comprehensively reformed, and institutional care is replaced by a range of suitable alternative care services that prioritise prevention and family-based up-bringing of children (Better Care Network 2017, p. 8; Opening Doors 2012; Nsabimana 2016). Instruments and practices

1 See for example studies by Engle et al. 2011; MacLean 2003; Beckett et al. 2002; Rutter et al. 1999; O'Connor and Rutter 2000; Makame et al. 2002.

2 See Guiney 2012; Pattisson 2014; Tuhinul and Fulcher 2016. 
geared towards curbing the expansion of institutional care settings and the promotion of family-based alternative care, have been put forward through a number of international meetings ${ }^{3}$.

As is well known, gaps in governments' provision of social services in Southern countries are often filled by NGOs. In Kenya, the care of children who are deprived of parental care is one such domain: children in such situations are brought up within kinship family contexts, certainly, but also increasingly within secular or faith-based private residential child-care institutions, run by NGOs and/or individuals. The role, structure, functioning, and legal obligations of these institutions - officially termed 'Charitable Children's Institutions' (CCI)—are outlined in the country's Children Act, which defines CCIs as, "a home or institution which has been established by a person, corporate or unincorporate, a religious organisation or a non-governmental organisation" and that, "has been granted approval by the Council to manage a programme for the care, protection, rehabilitation or control of children" (Laws of Kenya, Children Act 2001, section 58).

The Kenyan government's legislative activities related to child protection and its pro deinstitutionalization discourse, would seem to indicate a commitment to working towards deinstitutionalizing the up-bringing of children in the country. However, more and more children are still going into, and are remaining in institutional care and the number of known registered institutions still remains high. According to a collaborative Government of Kenya and UNICEF report, there were more than 830 charitable children's organizations in Kenya in 2015, where an estimated 40,000 to 42,000 children deprived of parental care were housed. The report is cautious in noting that the exact number of children is unknown (Government of Kenya, UNICEF, and Global Affairs Canada 2015, p. 8). Indeed, given the numerous press reports on the existence of illegally functioning residential care institutions around the country (see Guruba 2015; Benyawa 2016; Maichuhie 2016; Ucembe 2016), and with the number of 'orphans and vulnerable children' having been estimated at 3.6 million nationwide in 2015 (Government of Kenya, UNICEF, and Global Affairs Canada 2015, p. 6), one can expect that the numbers of institutionalized children may be much higher than the official figures.

Research that I conducted online shows that a growing number of these Charitable Children's Institutions, popularly known as 'orphanages', 'children's homes', or 'children's villages', are established as charity NGOs and are founded by 'do-it-yourself' ${ }^{4}$ individual humanitarians and/or by an association of persons. These small organizations (whose work is not correspondingly as small) are oriented towards external fund-raising and are almost entirely, if not fully, financially dependent on social actors from/in the global North. In order to secure the support of new donors from Northern countries, as well as maintain the funding they are already receiving, the large majority of these organizations have in recent years adopted a strategy that involves showcasing the children in their care, on their websites.

In this article I look at how in their quest to raise funds, do-it-yourself humanitarians and the organizations through which they run residential care institutions on the Kenyan South Coast, make use of the personal data of children in their care: individual children's photos, accompanied by their names and personal and/or family histories—for the most tragic—and details on their annual development are posted on the respective organizations' websites, making them accessible to the global public. I analyze and problematize this practice, positing that while it explicitly serves fund-raising purposes and is motivated by the search for cost-effective fund-raising-oriented communication, at a more implicit level, it is equally a strategy used to discursively legitimize ${ }^{5}$ the organizations and

3 Significant instruments include the Convention on the Rights of the Child (United Nations General Assembly 1989); the United Nations Guidelines for the Alternative Care of Children (United Nations General Assembly 2010); regional instruments such as the African Charter on the Rights and Welfare of the Child (Organization of African Unity OAU), and country specific ones such as Guidelines for the Alternative Family Care of Children (Republic of Kenya 2014).

4 By do-it-yourself humanitarians, I am referring to individuals who in this context are generally from the global North and who take on humanitarian responsibilities without necessarily having professional competence or experience in the domain.

5 My reference to discursive legitimation strategies denotes the specific ways in which the organizations and social actors within them-in particular their founders-make sense of, and assign meaning to their actions, activities and practices associated with their custody of, and care for children in their institutions. 
their child 'rescue' activities, within the contemporary climate of deinstitutionalization. This strategy results in a violation of children's rights; has ethical implications ${ }^{6}$; and is not without consequences for the concerned children's well-being. The aim of this paper is not to condemn the individuals or organizations in question, but rather, to point out gaps and contradictions in child protection that in an increasingly digitalised world, require urgent attention.

In the following section, I briefly discuss my methods and sources. This is followed by a presentation of the paper's theoretical background. I then discuss some of the key historical events to which one can trace the contemporary use of visual and literary representations of African children by western-funded NGOs, identifying some patterns and critiques that have been raised. This is followed by a description and analysis of two western-funded Kenyan children's institutions' websites-Sunshine and Greenfields ${ }^{7}$ - with regard to their use of personal data, images, and background stories of children in their care. Lastly, I discuss and conclude, offering possible solutions on how policy makers, and the so-called Charitable Children's Institutions and the individuals and organizations running them, can ensure confidentiality and respect for privacy in relation to children's personal data and information concerning their lives, in efforts to promote the overall protection of children. Due to space limitations, I do not provide descriptions of different aspects of the South Coast region; they are available in the literature (see for example Berman 2017; Chege (2014, 2015, 2017); Chege and Schweppe forthcoming).

\section{Methods and Sources}

This paper presents results from internet-based research that I conducted in 2017 on child rearing institutions in Kenya, and more specifically those situated on the Kenyan South Coast. Through the study, I sought to explore the identities, motivations, roles, and functioning of child-centered residential care institutions on the South Coast. My familiarity with the region through previous ethnographic research was pertinent for the study ${ }^{8}$.

I conducted online searches and identified the websites of nine children's institutions in the South Coast region that had the following characteristics: their founders or co-founders are nationals of global Northern countries (Germany, United Kingdom, France, Italy, The Netherlands and Australia) and are also the authors of the websites; the organizations through which the institutions are run exhibit dependency on external donations for sustenance (this is evident from their choice of language and/or currency, which tend to correspond to the founders' home region/country language and currency); and they showcase profiles of children in their care at varying degrees ${ }^{9}$.

I analyzed the content of the respective organizations' websites in relation to how each institution was presented; the 'kind' of children being looked after ('orphans', 'abandoned', 'neglected', 'abused', and 'orphaned and vulnerable children'); the identities and biographies of the founders; their projects; and how the reader is invited to 'get involved'. This led to an understanding of the kinds of issues that were being foregrounded by the organizations and the topics highlighted more generally when discussing their work. In the second phase, I narrowed down the data sources by selecting the web pages that were most relevant for my analysis: home pages, about us pages, and web pages featuring

6 While this is an ethical issue, in this paper I mostly discuss it from a legal angle, assuming that legal codes embody ethical requirements.

7 All names-the organizations' and children's—have been erased and pseudonyms are used in their place. Throughout this paper, quotations are presented as they appear in the source texts, but details such as names of people, places and dates that would allow one to easily trace back the children's profiles, have been altered. It is nonetheless not possible to guarantee non-traceability.

8 My research activities in the region began in 2009.

9 It is possible that websites published in other languages did not show up in the search results. I therefore make no claims to exhaustivity. 
individual children's profiles. I conducted an inter-discursive analysis ${ }^{10}$ (Wu 2011) of the corresponding web pages focusing on the various discourses used to situate the work of the organizations.

My analytic orientation was interpretative and critical. I adopted a critical discourse analytic perspective (Fairclough and Wodak 1997); more specifically a discourse-historical approach (Van Leeuwen and Wodak 1999), in that, in analyzing the issue of 'organizations' use of children's personal data online', I not only analyzed children's profiles on the organization's websites, but also integrated the larger historical and structural context into the analysis and interpretation of discourses and texts, which showed the embeddedness of literary and visual representations of African children in western humanitarianism. Like most studies that adopt a critical discourse analysis perspective with a strong emphasis on context, my analysis here entails methodological and theoretical eclecticism (Wodak 2002).

\section{Theoretical Background: Bridging Distance, Futility Thinking, and Cultivating Legitimacy}

The pattern of humanitarian assistance has always been clear: it flows from the global North to the global South, through the work of organizations and individuals who respond to both acute (emergency) situations and chronic crises and their socio-economic consequences. Since the second half of the 20th century, there has been a significant increase in the number of humanitarians and humanitarian organizations around the world, and in official and private humanitarian assistance funding, which in 1991 totalled an estimated 4.6 billion dollars, consistently rising annually to reach 27.3 billion dollars in 2016 (Development Initiatives 2000, p. viii; Development Initiatives 2017, p. 28).

Fund-raising being a cornerstone of humanitarian organizations' work and longevity, these organizations have to overcome three particular hurdles. As numerous researchers have noted, among them Chatterjee (2004); Lichtenberg (2012, p. 17); and Kennedy (2009), humanitarian organizations are confronted with, first, potential donors' inaction resulting from the latter's distance from those in need $^{11}$. Second, they have to grapple with 'futility thinking' and 'compassion fade' among potential donors (Västfjäll et al. 2014) resulting from the latter's constant access and exposure to flows of emotion-inducing news reports and imagery of a range of humanitarian 'disaster' situations through social and press media (Benthall 1993; Slovic $(2007,2010)$ ). Furthermore, these organizations have to contend with contemporary patterns of press media coverage through which affected people tend to remain nameless and faceless and their suffering abstract (Lichtenberg 2012; Kennedy 2009; Slovic (2007, 2010)), and through which information on distant happenings is almost always experienced as a case of 'fast news', which once consumed, is quickly forgotten by the global North viewer.

Whether big or small, charity organizations are increasingly seeking to curb inaction and compassion fade through media and fund-raising campaigns that use text and imagery to communicate the suffering or hardships of distant populations certainly, but also by specifically and strategically focusing on individuals or small groups of related individuals in need (Västfjäll et al. 2014; Slovic $(2007,2010)$ ). However, small charity organisations run by do-it-yourself humanitarians seeking to raise funds for their projects do not have the same communication and fund-raising budget capacities as do bigger organizations. Hence, exploring some aspects of the digital revolution, notably the widespread and ever-increasing availability of internet connectivity and affordability of websites and user generated content, has become the solution for small scale organizations.

As key communication resources, websites enable individuals, commercial and non-commercial organizations, to not only inform people about their activities, but also to spend less on communication, while simultaneously creating and defining their own brands; infusing personalities into their

10 Interdiscursive analysis involves analyzing the blend of discourses, genres and styles within a text and their relation to institutional and social meaning (Wu 2011, p. 96). For more on interdiscursivity see Wu (2011).

11 Here, distance needs to be understood as geographical distance certainly, but also as the absence of a moral, social and cultural connection (family, friendships, community attachment) between potential donors in the global North, and the affected people in a southern country context (Lichtenberg 2012, p. 17; Chatterjee 2004; Kennedy 2009). 
organizations; cultivating legitimacy; and/or generating income. For an annual cost of less than one hundred euros, any small NGO can produce and publish its own content online, which gives it a transnational reach. As Kennedy (2009) notes, such technology that allows users to generate content, stands as a threat to traditional press media.

In the field of charity, fund-raising and legitimacy are intricately connected, as are legitimacy and power. Rather than discuss the diverse ways legitimacy has been defined (see for example Dowd et al. 2008; Vidal et al. 2005; Suchman 1995), for the purpose of this paper, and because of space limitations, I draw on conceptualizations from social psychology and organizational sociology. In these fields, legitimacy is understood as generalized perceptions or assumptions with regard to the actions of an organization being desirable or appropriate within the frame of a socially constructed system of norms, values, and beliefs (Suchman 1995, p. 574). Comparatively, legitimacy is also explained as a state of appropriateness assigned to an actor, action, object, system, structure, or process that is the outcome of its integration within institutionalized norms, values, and beliefs; here 'actor' may refer to an individual, a group, an organization, a nation-state, or a world-system (Troyer 2011, p. 350). These two conceptualizations underscore the fact that legitimacy is socially constructed, and is a collective ascription, perception, or assumption. Depending on the specific context within which an NGO operates, actors who ascribe legitimacy or who hold assumptions about its legitimacy (or lack thereof) include the following: its members; other organisations in the sector; religious institutions; private companies; public administration; and members of society/citizens (Vidal et al. 2005).

Given that the missions of the large majority of NGOs are geared towards building more just societies, where certain values dominate, it may seem that the charity sector is intrinsically legitimate (Vidal et al. 2005, p. 8). However, an organization's status of legitimacy is not a given; it is dynamic in that it may be questioned despite the fact that there may be no change in its or its representatives' behaviour, practices or objectives (Deegan et al. 2002, pp. 319-20). Furthermore, studies have shown that NGOs do not necessarily take it for granted that working in charity organizations automatically legitimises them and their activities, and they thus engage in practices geared towards constructing legitimacy (Lavrusheva 2013; Lister 2003; Vaara et al. 2006; Vidal et al. 2005).

Important among these are discursive practices. Van Leeuwen and Wodak (1999) distinguish four general discursive legitimation strategies that are of relevance to this paper: authorization, rationalization, moral evaluation, and mythopeosis. Authorization involves reference to a particular authority, notably, tradition, custom, law, and individuals in whom some kind of institutionalized authority is vested; rationalization is understood as legitimation by reference to the function or utility of particular social practices or actions, and to socially constructed knowledge that endows them with cognitive validity; moral evaluation/moralization entails legitimation by reference to particular value systems; and lastly, mythopoesis/narrativization is the pursuit of legitimation through the linking of past, present, and future events (Lavrusheva 2013; Vaara et al. 2006; Van Leeuwen and Wodak 1999).

In order to understand and situate private residential child care institutions' use of children's data within global humanitarian dynamics and practices, I now turn to a historical exploration of the connections between western humanitarianism and the literary and visual representations of African children.

\section{Intersection of Western Humanitarianism and Literary and Visual Representations of African Children}

NGOs' work involving children on the African continent cannot be separated from its visual and literary representations. Disturbing images and descriptions of needy, suffering African populations and in particular poor, sick and/or starving African children, have been used and continue to be used to touch the hearts of persons in the global North, resulting in acts of financial and material generosity. These representations have also generated opposition and outrage: on the one hand, over 
the stereotyping and homogenization of people from African countries ${ }^{12}$ and on the other, with regard to the implied western and/or white superiority over African people (Dolinar and Sitar 2013; Manzo 2008; Van der Gaag and Nash 1987.)

It is beyond the scope of this paper to examine the entire country-by-country history of humanitarianism and how African children's images and their stories have been used in the fund-raising campaigns of NGOs. Rather, in what follows, I will discuss two key events to which one can trace the contemporary use of visual and literary representations of African children by NGOs, as well as patterns that emerged and critiques that have been raised, some of which are equally present and are relevant to understanding the fund-raising and legitimacy construction strategies of the small child-oriented organizations discussed in this paper.

The Nigeria-Biafra civil war represents a landmark event in the history of post-colonial humanitarianism and NGOs' use of images as an awareness and fund-raising strategy in relation to African children (O'Sullivan 2014). The 1967-1970 attempt by Biafra (the eastern region of Nigeria) to secede from Nigeria led to a three year long civil war, during which the Nigerian federal army deliberately blocked international aid missions' access and the delivery of food and medical supplies to Biafra (Baughan 2015; O'Sullivan 2014). While the Biafran leaders attempted to demonstrate legitimacy and raise awareness on the Biafran people's long-standing discriminated status within the larger Nigeria, the British, Russian, and American governments continued diplomatic and military support for the Nigerian federal government, and the western public remained unconcerned (Baughan 2015; O'Sullivan 2014; Heerten and Moses 2014). It was only televised and print images in western media, of critically malnourished Biafran babies and children struggling and dying of starvation that prompted a shift in the western public's stance, from one of indifference to one of solidarity (Heerten and Moses 2014; O'Sullivan 2014; Baughan 2015).

Through the initiative of a number of Aid Committees, most of which were formed during the Biafra-Nigeria war, relief supplies were airlifted into Biafara and starving malnourished children-who came to be referred to as "Biafran orphans" in press media-were later airlifted out of Biafra to relief camps in neighbouring African countries (Heerten and Moses 2014; O'Sullivan 2014; Baughan 2015). As Heerten and Moses have argued, these aid committees transitioned into some of today's large international NGOs, making way for a new form of humanitarianism. They believed in the importance of relaying to the world-principally through text and images—what they were witnessing in their regions of intervention (Heerten and Moses 2014, p. 177).

A pattern similar to the Biafran one can be noted in the awareness raising surrounding the 1983-85 Ethiopian famine that led to starvation, illness, and death of hundreds of thousands of Ethiopians. Graphic print and televised images of mostly Ethiopian children and women were used to raise awareness in western countries, through what became the advent of celebrity involvement in humanitarian fund-raising activities (Baughan 2015; Franks 2014). Central to these was the Live Aid initiative launched in 1984 by British musical entertainers, which spearheaded other massive fund-raising musical events held across Europe and the USA (Baughan 2015; Van der Gaag and Nash 1987). The Biafran-Nigerian and Ethiopian crises represent the first of many crises on the African continent where media and NGOs used fixed and moving images as an awareness raising and fund-raising strategy. In those early years, INGOs were typically big and relied heavily on press and televised media. Today, INGOs of varying sizes co-exist alongside each other, and technological advancements have gradually prompted these big and small actors to shift towards producing user generated content on their websites and through social media.

Some critiques have been raised in relation to NGOs' involvement in these two historical events and these can be extended to NGOs' work with children in the global South today. First, while graphic literary and visual representations of starving children and talk about the famine and humanitarian needs were circulated in the media through the work of western journalists, photographers, and NGOs, the political and social factors that had initiated and fuelled the respective famines were

12 See for example rustyradiator.com. 
not foregrounded and were thus left unaddressed (Baughan 2015; Franks 2014; O'Sullivan 2014). For example, on the Ethiopian crisis, Franks (2014) notes that journalists and western governments settled for the superficial explanation that the famine was caused by drought. Yet, there was evidence that the country's Mengistu Haile Mariam's authoritarian regime intentionally provoked the famine in the northern part of Ethiopia, where markets and trade related transportation were bombed as part of Ethiopia's civil war against Tigrayans and Eritreans. Furthermore, the country had a hefty military expenditure, with half its gross domestic product (GDP) going to defence (Franks 2014).

Second, the use of African mothers' and children's images in western humanitarian appeals for support emerged as a persistent feature and through their depiction of 'starving children', humanitarian organizations transmitted, and even today continue to transmit to donors the idea that they are superior relative to the people they are 'rescuing' (Baughan 2015, p. 12). Further, through such appeals NGOs have contributed towards establishing a paternalistic view of the relationship between donors from the global North and beneficiaries in the global South (Baughan 2015, p. 12).

Today, this paternalistic view is being reinforced through the work of child-centered intergovernmental organizations during periods of famine, armed conflict, and interventions related to containing the spread of HIV / AIDS and its social effects across numerous African countries. For close to two decades now, the dominant western imagination of children on the African continent is one of 'orphans', resulting from UNICEF's long-standing and on-going "Africa's orphan crisis" rhetoric, which has been picked up and propagated by other international governmental organizations, non-governmental organizations, national governments, as well as tour companies (Cheney and Rotabi 2014) .

In its efforts to underscore the plight of children affected by HIV/AIDS, in the early 2000s, UNICEF further introduced a broader definition of 'orphan', which was stretched to include even children who are left with one living parent (Cheney and Rotabi 2014). Orphaned children falling under the 'original' definition of orphan are thus termed 'double orphans', while those in the latter category are termed 'single orphans' (UNICEF $(2003,2006))$. The organization also widened its concern to include 'vulnerable children', understood as children who are themselves affected by HIV / AIDS (they themselves or one or both of their parents are HIV positive) or more generally, children who are affected by poverty, exclusion, or discrimination (their vulnerability being related or not to HIV / AIDS) (UNICEF 2003, p. 11; UNICEF 2006; Cheney and Rotabi 2014).

Two problems can be pointed out in relation to these definitions. First, as Cheney and Rotabi note, international discourse and perspectives on the situation have a tendency to uniquely lock in on the 'orphan', who is considered in isolation from her/his extended family and even from her/his larger community (Cheney and Rotabi 2014, p. 4). Second, in development discourse, these children are since then being referred to as "orphans and vulnerable children" (OVCs), and "vulnerable children" have also been discursively and strategically absorbed into the 'orphan' category.

Since the 1990s, there has been a general shift from public development aid (governments) to private aid (NGOs); rather than fund national governments in the global South, governments in the global North chose to fund humanitarian missions through NGOs and intergovernmental organizations. NGOs have thus been created, missions undertaken, and funds raised (and are still being raised) in the name of 'saving Africa's HIV / AIDS orphans'. Rather than question and challenge the underlying causes of child neglect, abandonment or orphanhood, fund raising campaigns in the form of African children's images are displayed in public spaces in cities of the global North.

Intergovernmental development organizations play a significant role in shaping NGOs strategies. Dolinar and Sitar (2013) for example, relate a campaign conducted between 2008 and 2010 in Slovenia, in which UNICEF used stereotypical life-size posters and televised images of African children, asking the Slovenian public to contribute towards getting children in Rwanda off the streets as well as bring smiles to children in Rwanda who had lost their parents (Dolinar and Sitar 2013, p. 23). The use of such images by UNICEF and many other humanitarian or developmental organizations simultaneously generates strong critiques expressed in academic literature, press and social media, yet ironically, it still contributes towards reinforcing these organizations' legitimacy (Manzo 2008; Dolinar and Sitar 2013). 
In what follows, I show the particular ways in which children's images and individual children's personal information, feature on the websites of two western-funded NGOs operating their residential care institutions on the Kenyan South Coast. I simultaneously point out the organizations' discursive legitimation strategies.

\section{Findings}

On the web pages of Greenfields and Sunshine, poverty, education (lack of), parental neglect and/or abandonment, orphanhood, HIV / AIDS and malnutrition are highlighted as the factors that led to the entry of these organizations into the lives of the children who are currently, or who were previously in their care. I distinguished the intertwining of three kinds of discourses. First, the 'white saviour complex discourse'-discourses that represent the local (non-white) people as socially and culturally flawed and as lacking the agency to resolve their own problems and marginality, thus needing the intervention of the white western humanitarians. Second, 'relief discourse' - these are humanitarian discourses in which children are depicted as innocent and endangered and their family members - mothers, fathers, grandfathers grandmothers-as weak, vulnerable, desperate and overwhelmed victims or villains, thus necessitating the intervention of white women and men from abroad. Lastly, 'deinstitutionalization discourse'-these are discourses and images that push forward the idea that once removed from their home family environment, the 'rescued' children are now happy and live in a family environment or that they find/found a 'new home' and/or 'family' at their respective institutions. The manifestation of these discourses is explored in the following sections.

\subsection{Analysis of Greenfields and Sunshine}

On their about us page, Bertha and Gerold, Greenfields' founding German couple, briefly note that they are a "small non-profit association" that has taken upon itself the "task to help in Kenya people in need". They pursue legitimation through the combination of white saviour narrativization, rationalization, and moralization when they briefly narrate that their 'children's village' project stemmed from earlier experiences during their holiday in the region, where they encountered "annoying" children who were "begging" and who got "contemptuous looks" from adults (moralization). They explain that their experience with seeing social inequality in the touristic South Coast region and "countless street kids", motivated them as a family ${ }^{13}$ to "devote their life to the children in need and abandoned babies" (rationalization, moralization).

According to information they provide on the website's about us page, and copies of official registration certificates available on the website, the couple created and registered the association through which Greenfields came into existence in Germany, in 1997. They registered as a CCI with Kenyan authorities in 2000 (authorization) and begun caring for eight children that same year. The number of children in their care increased gradually and although the exact number of children is not provided on the website, from individual children's profiles, it would seem that the organization's residential care institution currently has approximately fifty children in its care. The organization seeks support from Germans (German speaking population abroad or those visiting the region).

On Sunshine's about us page, Tara, its English founder, cultivates legitimation through a combination of white saviour narrativization, authorization, rationalization, and moralization. She explains that the orphanage was born out of her own experience with volunteering in a rural village in the South Coast in 2007, where she witnessed its community members' daily struggles and where she was "especially affected" by "children who had been orphaned or neglected" (moralization, rationalization). In 2008, she returned to the region to launch her project "with the support of friends, family and local businesses, schools, and churches" in the United Kingdom (authorization). She "gave

13 The couple has three children of their own: a teenage son, and two adult children who are also involved in supporting the running of the home. 
up her life in the UK to live in Kenya" (moralization), where she "worked with the community, village elders, and churches to identify the most desperate children" and by "personally researching each child's situation and history" (authorization). She registered the orphanage as a charity organization in the UK and as a CCI in Kenya (authorization). It became operational in 2010, starting out with five children and is currently responsible for thirty-five children. According to her, Sunshine is recognized as one of the best residential child-care institutions in the country and is lauded by the country's Children's Department as an example of 'best practice'. Sunshine is oriented towards securing support from the UK.

\subsection{1. "We Need Your Help"}

From as early as the home page of both organizations, it becomes clear that their websites-of which the children's profiles are a significant component-serve as fund-raising tools, and in a less evident way, to cultivate legitimacy. Sunshine's home page opens with a short introduction that geographically situates the institution and mentions its founder, who then engages in legitimation by rationalization and moralization, stating that the institution's role is not limited to providing basic needs_-food, shelter, and water- "for orphaned and vulnerable children", but also "quality education, love, security", as well as "hope for the future they truly deserve, in a family environment". This message is followed by a big outdoor 'family photo' captioned, "The Sunshine Family" featuring the founder, children of varying ages and some members of staff.

Reference to the institution oscillates between 'orphanage' and 'home': in matters related to fund-raising, the organization predominantly identifies Sunshine as an orphanage, while socially and administratively identifying it as a home. There is also an interesting juxtaposition of 'orphanage' and 'home' on its home page presentation ("Sunshine Orphanage is a children's home in [ ]"). As an essential social institution, the family is vested with a certain authority. Hence, the discourse and imagery of family and home is put forward for legitimation purposes. This strategy can also be understood as being shaped by the ongoing global pro deinstitutionalization rhetoric and actions.

The remaining two thirds of Sunshine's home page is dedicated to informing the western/global North reader that she/he can assist a child through sponsorship; announcing a fund-raising event; enumerating what two to twenty sterling pounds worth of donations can contribute to the children's institution; as well as informing about the possibility of volunteering at the institution. Several other smaller photos on the home page feature the founder with two or more of the institution's children.

On its home page, Greenfields invites the reader to "watch a video about our project", and alongside it informs her/him that "We help children in need!". While Greenfields has no other child-related projects elsewhere in Kenya or in other African countries, the German association through which the institution is run is said to be "a children aid project that supports Africa's orphans". Such discourses are typical of the relief sector, where small Northern organizations also adopt the discursive strategies known to generate funds ('helping Africa', 'supporting orphans'). Reference to Africa makes the organization appear bigger than it really is, and its work consequential. The same can be said of the domain name (internet address) chosen by the organization, where 'helping the country' features prominently.

In the video, Bertha and her family members (husband, adult daughter and son) narrate different aspects of the children's village, from its beginnings to its present state. The institution's children-babies through to young adults-as well as the founding couple's teenage son, are prominently featured in the fifty-minute video, which has mostly been taken in the institution and the surrounding environment. A short part of the video (approximately $3 \mathrm{~min}$ ) has been taken in Germany, where the founders' adult son is shown packing and sealing a cargo container containing donations and equipment to be shipped to the institution.

On both Sunshine's and Greenfields' website headers and sidebars, images of jovial looking children or chubby babies are prominent, and words like 'donate', 'sponsor', 'help now', 'click to donate', 'sponsor a child' and 'donation' feature prominently and/or recurrently on other pages 
dedicated to informing the readers how they can support the respective institutions' children. Readers are informed that they can make a donation; sponsor a child and can send money through trusted third party fund-raising websites or directly into the institution's bank account. It is also suggested that supporters can run fund-raising events for the benefit of the institutions. Greenfields' founder goes a step further by addressing companies, informing them that nowadays, companies are "highly scrutinised" and that "there are high expectations and responsibilities". They are thus encouraged to "Take on social responsibility" by making a contribution through their businesses and by giving back "some of your success to the orphans". It is important to note that the large majority of children in the care of Greenfields and Sunshine are not orphans, hence their reference to orphans here is purely strategic.

\subsubsection{The 'Before-After' Effect}

On Sunshine's website, the web pages dedicated to each child typically start by giving the date when the child joined the institution. This is followed by a photo whose caption states that this is where the child began his/her life. These photos-which I term the 'before photo(s)' - have been taken in the individual children's previous home compound or room. In them, the family's very modest to extreme living conditions are clearly visible (mud-walled, palm-thatched house, or-as is the case for two siblings-a housing structure erected in a garbage dump site). Present in the photos is usually the child in the company of his or her sibling(s) or with a member or two of their extended family. Babies and toddlers are often photographed in the arms of the founder. Generally, the ambiance in the photos is morose (which can be attributed to the combination of visible aspects of poverty and the children having to pose for photos with, and for people they are not familiar with). Additional before photos showing a child's previous life include those that illustrate 'extraordinary' conditions such as a child's jigger-infested feet or children in the garbage dump site that was their home.

Beneath each child's before photo, her/his background is briefly provided and is narrated in an entertaining but emotion-inducing tone. The exclamation "This is what living at Sunshine achieves!" routinely follows every such biography, and is then followed by a slide show of two or more 'after photo(s)', that is, photos of the child taken within the context of the institution, either individually or in the company of a sibling or the founder. Generally, the child is well groomed and beaming (which may be attributed to their then familiarity with the institutional environment and the photographer-who in all likelihood is the founder and who may encourage them to smile). These after photos are usually followed by two or three lines through which the reader learns that the child is now happy; there is some reference to his/her character; academic abilities; and likes.

Comparatively, on Greenfields' website, the web pages dedicated to each child also follow a similar pattern, but are disturbingly detailed. Each child's precise or officially assigned date of birth (day of the week, date, month and year) is provided at the very beginning of her/his profile. This is followed by a detailed "history" of the child, narrated through Bertha's voice and who communicates the disturbing events that led to her and her organization's entry into the particular child's life. Through her narratives, the reader experiences an oversimplified 'before-after effect'. For example, we learn that, "After living in an impoverished life, Maana came to us with physiological disorders. She was very reserved never laughed.", and that, "Now, Maana is a friendly girl without problems and fears".

Each child's history is followed by highlights of her/his yearly development, which comes under the heading "career". The reader is given information through which she/he gets to know almost every aspect of each child's development-a child's academic aptitude ("Jane is now in class 7 and an average performer"); their leisure activities and personality ("She plays hand- and netball and attends the drama club"); and behaviour and character traits at different stages of the child's life ("Our Jane is sometimes somewhat difficult, what leads sometimes also to problems in the school" and "She is at the moment in an awkward age and is sometime not respectful enough"). The founder's joys, reservations, and disappointments in the children's academic abilities and performance are also put across, "We hope Ijumaa will finish Primary School with success end of the year. However, we are 
prepared that her marks might not be good enough to be taken in by a Secondary School" and "Ali has finished Primary School [ ] to his and our great disappointment with such bad marks that it would be a waste of time to send him to Secondary School". It is important to bear in mind that alongside all the information given on each child, the reader is provided with several chronologically posted photos of the child, from the time she/he joined the institution, to date.

\subsubsection{The Urgency and Legitimacy of Rescuing Orphans, Abandoned and Neglected Children}

The image and discourse of 'rescue' is present in the strategically crafted children's profiles. The discourse of rescue is often coupled with a sense of urgency. On Greenfields website, almost every child's story starts and reads like a personal diary entry and is communicated as a very urgent situation:

"On 5 July 2006, we received once again a phone call from the Youth Welfare Office. A newborn cannot stay with his mother and needs to be picked up."

“On 29 November 2009, we were called to come to the hospital in Mmoja."

"On 10 January, I, Bertha, am called to the phone by our accountant Bob. It is urgent he says."

"On Sunday morning, 22 of June 2012, we received a phone call from the local police. A baby was abandoned near Sita River."

"On 18 August 2015, our team in Kenya was called again by the local youth welfare office. They said that a baby in Galu, around two weeks old, urgently needed help."

The tone of the narratives is entertaining, with an emphasis on drama, which resembles press media techniques that serve to instantly capture the attention of the reader. The interventions involve the founders, the institutions' social workers and the local youth welfare office and/or the police. Greenfields' reference to their contact with police (on 32 children's profiles), hospitals and the area's youth welfare office(rs) (on 18 children's profiles) needs to be understood as an impersonal and personal authorization legitimation strategy ${ }^{14}$, where reference is made to public authorities, such as police, the chief, the local youth welfare officer, the youth welfare office, the court and the children's department. The authority of these figures is communicated within narratives that show the degree of their power. For example, on one child's profile, Sunshine's founder narrates that "It was during this time that Sunshine were asked by the Chief of the area to visit the family to see if we could assist". Reference to such authority figures serves to establish legitimacy for specific actions and for the respective organizations, by demonstrating their founders' personal and the organizations' social and legal integration in the region and the country.

As the main representatives of their organizations, founders relate how they and their institutions "save" or "rescue" children from a variety of circumstances that present a threat to the children's lives and well-being. Mothers come across as sources of particular danger for the rescued children. For example, from some of Greenfields' children's profiles, one learns of a child who arrived to the institution as a new born baby abandoned in bushes, while another was abandoned on the roadside; a baby whose life was in danger because her mother threatened to "kill the girl" if nobody accepted to take the baby in before the end of the day; a baby whose mother was spotted sitting on her in an attempt to suffocate her; and a neglected toddler whose 'half-uncle' raped her and whose mother abandoned her at the hospital where she had brought her for observation.

Legitimation for separating children from their family context is cultivated through presenting the mothers as irresponsible, irrational and potentially violent. Sunshine's founder relates how she and her team urgently "rescued" two siblings (aged between 8 and 10 years) who were living with their mother in a garbage dump (that the founder explains was also home to other families). She narrates how having failed to convince the children's mother that the garbage dump was hazardous for her

\footnotetext{
14 For more on narrativization and impersonal and personal authorization legitimation strategies see Lavrusheva 2013.
} 
children, she and her partner, in the company of their children's officer, "removed and rescued these two distraught children" and that "they are now safe at Sunshine in a clean loving environment".

On some children's profiles, mothers are represented as both villains and victims. For example one learns that Sunshine took in two siblings whose mother died as "She had been consuming elicit brew" and that she had been making a living "however she could", because "life was desperate!". The founder also describes the situation of two siblings who were the outcome of sexual assaults endured by their mentally ill mother. Legitimation is pursued through rationalization and moralization as these and other babies and children are portrayed as having been 'rescued' from their unfit and or/sick mothers. Some mothers are described as 'desperate', 'sick', 'confused', 'drug addicts', and as 'prostitutes' and/or suffering from 'mental illness'. In most children's profiles, no reference is made regarding their fathers. However, where they are mentioned, it is in relation to their death, illness and more rarely, to communicate the intervention of the organisation as originating from the concern certain struggling fathers and elderly grandfathers had for the well-being of their children/grand children.

Malnourishment is a common theme on the children's profiles and one through which mothers are depicted more as helpless victims than villains. On the Greenfields website, some children's profiles feature images of nude or clothed undernourished babies or toddlers, presented with a before-after effect. Greenfields' founder relates the state of malnourishment in which she found one of the children in her care: "What we found at the hospital was a malnourished 14-month old girl named Leah". Her mother is described as having been "entirely desperate or confused", as she "sat at the sick bed with her three little children: Lina around three years old, Leah, and a three-month-old baby". Children are also described as having "arrived neglected, underfed and hungry" at the institution. It is also worth noting that the malnourished state in which children were in on arrival, is used as their profile title, thus defining them online ("Leah, an underfed child, finds refuge in Greenfields"). Comparably, on one child's profile featuring before-after photos, Sunshine's founder invites one to "Look just how malnourished Joseph is". On another child's profile we learn that "After coming to Sunshine Caro would try to eat the most unusual things, even dirt from the ground as a result of her poor diet".

Additionally, most children are also 'saved' from poverty. On the profiles of some children on both institutions' web pages, one learns that despite having parents who are known to the institution, numerous children live in the institutions because they come from poor struggling households and/or large families whose parents or guardians (in particular grandparents) cannot adequately provide and look after them. For example, the founder of Greenfields narrates how three children from a family of 11 siblings were 'saved'. Their mother is said to be "just a housewife" and their father "a peasant fisherman". Legitimation is cultivated through reference to "good education" as an institutional authority. For example, Bertha rationalizes the legitimacy of her organization's intervention in these children's lives (separating the children from their parents and poor family environment) by noting that given the big size of the family, it is uniquely "through good education" that the children in question "will change their lives to better in future".

The HIV status of children is projected as a major concern, and is also liberally communicated on their profiles and the institutions' online announcements. Preoccupation with, and motivations for determining the HIV status of children is different for the two institutions. On two siblings' respective profiles, Sunshine's founder informs that children who join the institution are systematically given a full medical check up and blood tests, including HIV screening, "so that appropriate medication and care can be given if required". Conversely, at Greenfields, HIV testing is/has been key in determining whether or not a child gets to stay and grow up in the institution or whether she/he would be sent to institutions that specifically care for children who are HIV positive.

The uncertainty surrounding some children's future in Greenfields is perceptible on the founder's earlier entries on some children's profiles. These are generally abandoned babies or toddlers whose mothers' HIV status was unknown or was known to be positive. For instance, on one abandoned baby's profile the reader is informed that "In 5 to 6 weeks, Bobby needs to go to the hospital again for an HIV test. We hope that he is HIV negative and can stay in the children's home" and that "If Grace 
should be HIV positive, she cannot stay with us and will be transferred to Mombasa [ ]". The results of children's HIV screening are also communicated on their profiles and on Greenfields' news posts. The title of a subsequent news post on the institution's website reads: "Good news: Bobby is HIV negative [ ] and can stay with us" and that Grace "is HIV negative and can stay with us".

\section{Discussion and Conclusions}

The organizations whose website content I have described and analyzed here could have chosen to simply provide general, collective narratives on the children in their care. This was however, not their choice. Websites are a key cost-effective communication resource that these small child-oriented organizations have chosen to bridge the distance (geographical, social, cultural and economic) between their potential global Northern donor public and the children in their care.

At a first and seemingly more evident level, these organizations' choice to give individualised, detailed information on each child can be understood simply as a fund-raising strategy. In a global Northern context where access and exposure to flows of news reports and imagery of a range of humanitarian 'disaster' situations is the order of the day, these individual children's images and background plight stories are expected to contribute towards curbing futility thinking and compassion fade. It is anticipated that they will elicit strong emotional reactions among potential donors, which could be followed through with acts of generosity in the form of financial and/or material support.

At a deeper level, the use of these data and rescue stories can be understood as a process of legitimacy construction, not only in relation to the organizations' and their founders' interventions in each individual child's life, but also with regard to the legitimacy of each organization and its founder's long-term presence in the region. All of the analyzed children's profiles show clear use of mythopoesis-legitimation through the telling of stories (Van Leeuwen and Wodak 1999). Narratives about past situations that represent gloom, hardships, ill-being and in some cases danger for a child, are told so as to give a sense of the appropriateness of the associated rescue behaviour and actions that need to be legitimized, and which collectively contribute to perceptions of the appropriateness of the organization and its interventions. The layout of the children's profiles and the structures of the narratives (still and moving images and text) are also narrativization legitimation strategies as they implicitly urge the reader to make comparisons between a child's past life (prior to arriving in the institution) and their present situation (psychological and social aspects) or future (life prospects), which leads the reader to view the organization's activities and interventions as appropriate and justified.

These organizations' use of children's personal data on their websites is paradoxical, in that, it may be understood as tied to humanitarian action, but also as exemplary of contemporary colonial-like practices. Although children's profiles are created and used to raise funds for their needs, the content of individual children's profiles violates a key component of humanitarian principles-respect for human dignity-which is expressed in a range of NGO codes of conduct (see for example ICRC (1991) and OCHA (2012)). Respect for human dignity is also a key component of the guiding principles of the 2006 Code of Conduct on Images and Messages (Dóchas 2014) that has been adopted by a range of NGOs working in the development and humanitarian fields ${ }^{15}$. With respect to this, there is disregard for the requirement to treat those in need and/or beneficiaries of support (in this case children, their parents and families) as subjects, who have agency and more specifically to treat them with dignity and refrain from representing them as hopeless victims or objects in the organizations' information and publicity activities (ICRC 1991; Dóchas 2014). This is also an illustration of the contradictions pointed out by Manzo (2008) and Kennedy (2009) in relation to NGOs' skewed and selective respect

15 The Dóchas Code of Conduct on Images and Messages has a longer history dating back to 1989. It has been revised over the years in response to North-South representation challenges, experienced through the development and humanitarian fields (see Manzo 2008, pp. 637-38). 
for humanitarian principles, in their representations of the distant Other and Other's children for fund-raising purposes.

A colonial-like paternalistic mindset, it would seem, underlies the organizations' and their founders' actions; they selectively respect humanitarian principles and the rights of the children in their care, and operate in a manner indicating that they consider that while children have rights, the degree to which those rights are respected depends on a child's country of birth and residence. The status of being an African child, who resides in an African country and who comes from a background of poverty and/or family instability, is implicitly considered justification for an organization's selective respect for the child's right to confidentiality and to living a private life.

From both legal and ethical points of view, Charitable Children's Institutions have a responsibility to respect the dignity of children in their care, this being a fundamental and core principle of humanity when engaged in assisting and representing persons affected by, or living through a crisis. In publicizing the personal stories of children in their care, the institutions in question make information that is meant to be private and/or confidential accessible to the global public and are thus also violating their obligation to respect confidentiality with regard to each child's personal data. The United Nations Guidelines for the Alternative Care of Children, which is derived from the United Nations Convention on the Rights of the Child (United Nations General Assembly 1989), outlines this obligation. In particular, Article 110 of the guidelines is concerned with residential care institutions' obligation to respect confidentiality in their handling of children's personal information:

The records on children in care should be complete, up to date, confidential and secure, and should include information on their admission and departure and the form, content, and details of the care placement of each child, together with any appropriate identity documents and other personal information. Information on the child's family should be included in the child's file, as well as in the reports based on regular evaluations. This record should follow the child throughout the alternative care period and be consulted by duly authorized professionals responsible for his/her current care (United Nations General Assembly 2010, p. 17).

Other national instruments such as the Guidelines for the Alternative Family Care of Children in Kenya (Republic of Kenya 2014); National Standards for Best Practices in Charitable Children's Institutions (Republic of Kenya 2013a); and the Training Manual for Charitable Children's Institutions in Kenya (Republic of Kenya 2013b) (which flow from The United Nations Guidelines for the Alternative Care of Children), as well as the Charitable Children's Institutions Regulations (Kenya Gazette Supplement 2005), also emphasize this obligation.

It is worth noting the distinction made between confidentiality and privacy in the National Standards for Best Practices in Charitable Children's Institutions: "Confidentiality pertains to information and records while privacy pertains to an individual's space and body" (Republic of Kenya 2013a, p. 13). However, from the same document, it is evident that confidentiality and privacy are intertwined and privacy can be understood from other angles:

All children are entitled to privacy and no written material or files containing a child's information should be left exposed for all to view. There should never be any public discussion about a child's sensitive issues, either in the presence of the child or other people who work or do not work within the CCI. Caregivers should be trained on confidentiality and sensitivity of information (Republic of Kenya 2013a, pp. 31-32).

Thus, confidentiality, which is an ethical requirement, can impact privacy, which is a right that is enshrined in both national and international laws. Public disclosure of private facts concerning individual children and showcasing of their private lives by CCIs, their founders and by the organizations through which the former are managed (whether this exposure is related to a child's family and home environment or within the residential care institution), is in violation of Article 16 of the Convention on the Rights of the Child, which stipulates that children are entitled to privacy, and 
that national laws ought to protect them against intrusions that violate their privacy at personal, family, and home levels (United Nations General Assembly 1989).

These violations have implications for the well-being of the concerned individual children. Research conducted among care-leavers in Kenya has shown that many young adults who spent their childhoods in institutions experience difficulties later in life, stemming from the 'victim' identities assigned to them by their residential care institutions and social actors within them (Ucembe 2013). In particular, the orphan identity has an impact on their self-esteem from childhood to adulthood. In his research on care leavers, Ucembe notes that the designation 'orphan', "reinforces physical exclusion: the space between "us" and "them" ", as well as social exclusion since children who are discursively and strategically identified as "orphans" are treated differently, which reinforces their social positions and identities as "the Other". He notes that often, the label orphan is negatively connoted in that one is stereotypically perceived as an object of pity and in search of sympathy, which subsequently negatively impacts self-identity (Ucembe 2013, p. 17).

In the institutions that are the subject of my study, this orphan labelling trend is perverse in that it goes a step further: not only are the children labelled orphans, but their orphanhood (whether real or strategically constructed) is also presented to the global public through narratives containing very personal information. As internet technologies evolve, it is very likely that this data will still be available online even long after it has been deleted from the source websites.

A question that one needs to ask is, why are such practices possible in Kenya and in some countries of the global South, but are not in those of the global North? A first explanation could be the fact that child protection has been fully delegated to the humanitarian private sector (by the State to CCIs-see Ucembe 2015), including the financing of child protection measures. This serves to reinforce the already existent unequal donor-receiver relationship, in that the NGOs and individuals who 'donate' their services to the State-which has chosen to be minimally involved in child protection from a social services perspective-are construed as selfless and charitable. Conversely, the children in their care are collectively construed as passive, needy sufferers who do need protection, but who need not be consulted on the form it takes (Ucembe 2015). This translates into the NGOs enjoying considerable leeway and power with regard to decisions they take concerning individual children in their care.

Second, as has been shown through the 'creation stories' of Sunshine and Greenfields, these institutions come into existence through the personal encounters of their founders with social inequality during their visits to the region as tourists or as voluntourists. A white saviour complex is born or reified through such experiences, as the individuals give up their lives elsewhere and make 'saving' African people personal or family missions. In most cases, the founders do not have the professional training or experience needed to work with children or run such institutions (out of the nine South Coast residential child care institutions I analyzed, only one founder had professional child-related experience-teaching. However, her organization's website had some of the most cliché 'Westerners saving Africans' imagery and rescue discourses).

This white saviour complex is met and propped up by a post-colonial complex: the fact that some persons (white) from the global North make 'helping Africans' a personal or family mission and regularly visit or move to the region, bringing in financial and material resources, appears to be a good enough condition for local community members and for regional and central authorities. The suitability and professional qualifications of those who seek to set up and run residential child care institutions is rarely evaluated, if at all, during and after the organizations' official registration. This is evident from the insensitive and unprofessional handling of children's personal data by founders and their organizations—as shown by my research—and the very fact that registering a children's 
residential care institution is literally open to anyone ${ }^{16}$. Thus, the underlying assumption is that any white person has the capacity to run a residential care institution for African children.

The discourses and actions motivated by the white saviour complex contribute towards the establishment of a paternalistic view of the relationship between the organisations' foreign donors and the local beneficiaries (children, mothers, fathers and the community at large). The white saviour complex is conjoined with a 'This is Africa' attitude. Underlying the latter is the idea that do-it-yourself humanitarians and their organizations need not act or relate with or about people in the country in the same way as they would be expected to in their own countries because, 'Things are different in Africa'.

These findings have policy implications. Current conceptions of privacy in Kenya's legislation-in particular the aforementioned instruments related to children in residential care-refer uniquely to physical bodily privacy that the institutions are expected to guarantee through the provision of suitable and adequate amenities (toilets, bathrooms and separate bedrooms). In Kenya's Children Act, reference to children's right to privacy is at best cursory and vague: Article 19 of the Children Act simply states, "Every child shall have the right to privacy subject to parental guidance." (Laws of Kenya, Children Act 2001). From a legal angle, the meaning of respect for children's privacy needs to be extended to include the obligation to respect children's right to living private lives. From a regulatory angle, strengthening and extending the motoring and supervision of residential child care institutions beyond their physical existence and functioning is crucial. In this age of digital connectivity, it is important that child protection authorities monitor how residential care institutions represent the children in their care online.

For NGOs and individuals from the global North who are running residential child care institutions, it is crucial that a shift be made from viewing children in their care as victims and/or objects of care to subjects who have futures as adults, and to whom they will be accountable. In their representation of children, contemplating a number of questions is necessary. First, it is worth considering whether it is in the best interests of a child to have their personal details and private life spread out on an internet page that is indiscriminately open to the global public. Second, it is important to consider whether the stories they relate and images they share on their websites are respectful of the child, and given that children's privacy is firmly protected in most countries of the global North, it is worth questioning whether from legal, ethical, and moral perspectives they would share similar information about a child in their countries of origin in the same or similar ways. Third, these considerations need to be looked at from not only a short-term view, but equally from a long-term perspective, in terms of whether the images and stories shared about a child today could be detrimental to their future well-being. Lastly, individual profiles would perhaps best be reserved for children who are old enough to give informed assent or dissent.

Funding: This research received no external funding.

Acknowledgments: The author wishes to thank Fred Seidel for his constructive comments on an earlier version of this paper, and the two anonymous reviewers for their additional critical reading of the article.

Conflicts of Interest: The author declares no conflicts of interest.

\section{References}

Baughan, Emily. 2015. Humanitarian Images and Appeals in history. In The Radiator Report Challenging the Single Story. SAIH. Available online: https:/ / saih.no/assets/docs/Radiator-Report-2015.pdf (accessed on 9 October 2017).

Beckett, Celia, Diana Bredenkamp, Jenny Castle, Christine Groothues, Thomas G. O'connor, and Michael Rutter. 2002. English and Romanian Adoptees (ERA) Study Team. Behavior patterns associated with institutional deprivation: A study of children adopted from Romania. Journal of Developmental and Behavioral Pediatrics 23: 297-303. [CrossRef] [PubMed]

16 According to a press media report, in 2017 an American teenager was authorized to establish a children's home in Kenya. See Morris (2017). 
Benthall, Jonathan. 1993. Disasters, Relief and the Media. New York: I. B. Tauris \& Co.

Benyawa, Linah. 2016. 'Most Children's Homes in Mombasa County Are Illegal, Official Warns'. The Standard Digital, April 23. Available online: https://www.standardmedia.co.ke/article/2000199333/ most-children-s-homes-in-mombasa-county-are-illegal-official-warns (accessed on 7 October 2017).

Berman, Nina. 2017. Germans on the Kenyan Coast. Bloomington and Indianapolis: Indiana University Press.

Better Care Network. 2017. Deinstitutionalisation of Europe's Children. Opening Doors for Europe's Children. Available online: https://bettercarenetwork.org/sites/default/files/OD_DI_QA_07122017.pdf (accessed on 3 January 2018).

Chatterjee, Deen. K. 2004. Introduction. In The Ethics of Assistance: Morality and the Distant Needy. Edited by Deen K. Chatterjee. Cambridge and New York: Cambridge University Press, pp. 1-10.

Chege, Njeri. 2014. Male Beach Workers and Western Female Tourists: Livelihood strategies in Kenya's South Coast Region. Unpublished Ph.D. thesis, University of Lausanne, Lausanne, Switzerland.

Chege, Njeri. 2015. "What's in It for Me?" Negotiations of Asymmetries, Concerns and Interests between the Researcher and Research Subjects'. Ethnography 16: 463-81. [CrossRef]

Chege, Njeri. 2017. 'Towards a Deeper Understanding of the Meaning of Male Beach Worker-Female Tourist Relationships on the Kenyan Coast'. Journal of Arts and Humanities 6: 62-80. [CrossRef]

Chege, Njeri, and Cornelia Schweppe. Tourism, Charity and How to Get a Sponsor for Children's Education: Fundraising strategies of households on the Kenyan coast. Journal of Child, Youth and Family Studies, forthcoming.

Cheney, Kristen E., and Karen Smith Rotabi. 2014. Addicted to Orphans: How the Global Orphan Industrial Complex Jeopardizes Local Child Protection Systems. In Conflict, Violence and Peace, Geographies of Children and Young People. Edited by Christopher Harker, Kathrin Hörschelman and Tracey Skelton. Singapore: Springer, vol. 11.

Deegan, Craig, Michaela Rankin, and John Tobin. 2002. An examination of the corporate social and environmental disclosures of BHP from 1983-1997: A test of legitimacy theory. Accounting, Auditing \& Accountability Journal 15: $312-43$.

Development Initiatives. 2000. Global Humanitarian Assistance Report 2000. Bristol and Nairobi: Development Initiatives. Development Initiatives. 2017. Global Humanitarian Assistance Report 2017. Bristol and Nairobi: Development Initiatives.

Dóchas. 2014. Code of Conduct on Images and Messages 2006. Produced by the Irish Association of Non-Governmental Development Organisations-DOCHAS. Available online: http://www.dochas.ie/ images-and-messages (accessed on 18 January 2018).

Dolinar, Maja, and Polona Sitar. 2013. The Use of Stereotypical Images of Africa in Fundraising Campaigns. Jorind 11: 251-57.

Dowd, Timothy, Cathryn Johnson, and Cecilia L. Ridgeway. 2008. Legitimacy as a Social Process. Annual Review of Sociology 32: 53-78.

Engle, Patrice L., Gary Nelson Gamer, and Emily Vargas-Barón. 2011. Early Childhood Development What Parliamentarians Need to Know and Do. Geneva: Unicef Regional Office for Central and Eastern Europe and The Commonwealth of Independent States.

Fairclough, Norman, and Ruth Wodak. 1997. Critical discourse Analysis. In Discourse as Social Interaction. Edited by Teun A. Van Dijk. London: Sage, pp. 258-84.

Franks, Suzanne. 2014. Ethiopian Famine: How Landmark BBC Report Influenced Modern Coverage. Available online: https://www.theguardian.com/global-development/poverty-matters/2014/oct/22/ ethiopian-famine-report-influence-modern-coverage (accessed on 18 September 2017).

Government of Kenya, UNICEF, and Global Affairs Canada. 2015. Taking Child Protection to the Next Level in Kenya. Available online: https:/ / www.unicef.org/protection/files/Kenya_CP_system_case_study.pdf (accessed on 5 December 2017).

Guiney, Tess. 2012. 'Orphanage Tourism' in Cambodia: When Residential Care Centres Become Tourist Attractions. Pacific News $\mathrm{N}^{\circ}$ 38, July/August. Available online: https://bettercarenetwork.org/sites/ default/files/Orphanage\%20Tourism\%20in\%20Cambodia\%20-\%20When\%20Residential\%20Care\% 20Centres\%20Become\%20Tourist\%20Attractions.pdf (accessed on 16 March 2018).

Guruba, Simon. 2015. Ukunda Children Home Closed Down for Lack of Registration Certificate. Kenya News Agency, July 4. Available online: http:/ / kenyanewsagency.go.ke/en/ukunda-children-homeclosed-down-for-lack-of-registration-certificate/ (accessed on 7 October 2017).

Heerten, Lasse, and A. Dirk Moses. 2014. The Nigeria-Biafra war: Postcolonial conflict and the question of genocide. Journal of Genocide Research 16: 169-203. [CrossRef] 
ICRC. 1991. The Code of Conduct for the International Red Cross and Red Crescent Movement and Non-Governmental Organisations (NGOs) in Disaster Relief. Available online: http://www.ifrc.org/ Global/Publications/disasters/code-of-conduct/code-english.pdf (accessed on 11 April 2018).

Kennedy, Denis. 2009. Selling the Distant Other: Humanitarianism and Imagery-Ethical Dilemmas of Humanitarian Action. Journal of Humanitarian Assistance. Available online: https://sites.tufts.edu/jha/ archives/411 (accessed on 15 November 2017).

Kenya Gazette Supplement. 2005. The Children (Charitable Children's Institutions) Regulations. Kenya Gazette Supplement No. 89. Available online: http:/ / www.bettercarenetwork.nl/dl-17382-1-28844/download/cci_ regulations.pdf (accessed on 8 November 2017).

Lavrusheva, Olga. 2013. Discursive Legitimation Strategies in the Media. Case Study of the UK Retail Planning Policy. Unpublished Master's thesis, Aalto University School of Business, Helsinki, Finland.

Laws of Kenya, Children Act. 2001. Children Act, Chapter 141, revised edition 2010 (2007). Published by the National Council for Law Reporting/Kenya Law. Available online: https:/ /bettercarenetwork.org/sites/ default/files/The\%20Children\%27s\%20Act\%2C\%20Kenya_0.pdf (accessed on 4 December 2017).

Lichtenberg, Judith. 2012. Absence and the Unfond Heart: Why People Are Less Giving Than They Might Be. In The Ethics of Assistance Morality and the Distant Needy. Edited by Deen. K. Chaterjee. Cambridge and New York: Cambridge University Press.

Lister, Sarah. 2003. NGO Legitimacy: Technical issue or Social Construct. Critique of Anthropology 23: 175-92. [CrossRef]

MacLean, Kim. 2003. The impact of institutionalization on child development. Development and Psychopathology 15: 853-84. [CrossRef] [PubMed]

Maichuhie, Kamau. 2016. Orphanage Closed over Claims of Child Molestation. The Standard Digital, April 1. Available online: https:/ / www.standardmedia.co.ke/article/2000196780/orphanage-closed-over-claimsof-child-molestation (accessed on 7 October 2017).

Makame, V., C. Ani, and Sally Grantham-McGregor. 2002. Psychological well-being of orphans in Dar El Salaam, Tanzania. Acta Paediatrica 91: 459-65. [CrossRef] [PubMed]

Manzo, Kate. 2008. Imaging Humanitarianism: NGO Identity and the Iconography of Childhood. Antipode 40: 632-57. [CrossRef]

Morris, Sarah. 2017. Arkansas Teen Creates Children's Home in Kenya. Us News and World Report, December 3. Available online: https:/ / www.usnews.com/news/best-states/arkansas/articles/2017-12-03/arkansasteen-creates-childrens-home-in-kenya (accessed on 2 March 2018).

Nsabimana, Epaphrodite. 2016. The Process of Institutionalization-Deinstitutionalization and Children's Psychological Adjustment in Rwanda: Parents Matter. Ph.D. thesis, University of Fribourg, Fribourg, Switzerland.

O'Connor, Thomas G., and Michael Rutter. 2000. Attachment disorder behavior following early severe deprivation: Extension and longitudinal follow-up. English and Romanian Adoptees Study Team. Journal of the American Academy of Child and Adolescent Psychiatry 39: 703-12. [CrossRef] [PubMed]

O'Sullivan, Kevin. 2014. Humanitarian encounters: Biafra, NGOs and imaginings of the Third World in Britain and Ireland, 1967-70. Journal of Genocide Research 16: 299-315. [CrossRef]

OCHA. 2012. OCHA on Message: Humanitarian Principles. Available online: https:/ /www.unocha.org/sites / dms/Documents/OOM-humanitarianprinciples_eng_June12.pdf (accessed on 14 April 2018).

Opening Doors. 2012. Deinstitutionalisation and Quality Alternative Care for Children in Europe: Lessons Learned and the Way Forward. Brussels: Eurochild Working Paper.

Organization of African Unity (OAU). 1990. African Charter on the Rights and Welfare of the Child (ACRWC). Addis Ababa. Available online: http:/ / www.acerwc.org/acrwc-full-text/ (accessed on 14 June 2017).

Pattisson, Pete. 2014. Nepal's Bogus Orphan Trade Fuelled by Rise in 'Voluntourism'. The Guardian, May 27. Available online: https:/ / www.theguardian.com/global-development/2014/may/27/nepal-bogus-orphantrade-voluntourism (accessed on 10 November 2017).

Republic of Kenya. 2013a. National Standards for Best Practices in Charitable Children's Institutions. Available online: https:/ / bettercarenetwork.org/sites/default/files/National\%20Standards\%20for\%20Best $\%$ 20Practices\%20in\%20Charitable\%20Children\%27s\%20Institutions.pdf (accessed on 8 November 2017).

Republic of Kenya. 2013b. Training Manual for Charitable Children's Institutions in Kenya. Available online: http:/ / bettercarenetwork.org/sites/default/ files / Training\%20Manual\%20for\%20Children \% $27 \mathrm{~s} \%$ 20Institutions\%20in\%20Kenya.pdf (accessed on 9 November 2017). 
Republic of Kenya. 2014. Guidelines for the Alternative Family Care of Children in Kenya. Available online: http://www.bettercarenetwork.org/sites/default/files/Guidelines\%20for\%20the\% 20Alternative\%20Family\%20Care\%20of\%20Children\%20in\%20Kenya.pdf (accessed on 9 November 2017).

Rutter, Michael, Lucie Andersen-Wood, Celia Beckett, Diana Bredenkamp, Jenny Castle, Christine Groothues, Jana Kreppner, Lisa Keaveney, Catherine Lord, and Thomas G. O'Connor. 1999. Quasi-autistic patterns following severe early global privation. English and Romanian Adoptees (ERA) Study Team. Journal of Child Psychology and Psychiatry 40: 537-49. [CrossRef] [PubMed]

Slovic, Paul. 2007. "If I look at the mass I will never act": Psychic numbing and genocide. Judgement and Decision Making 2: 79-95.

Slovic, Paul. 2010. The more who die, the less we care. In The Irrational Economist: Making Decisions in a Dangerous World. Edited by Erwann Michel-Kerjan and Paul Slovic. New York: Public Affairs Press, pp. 30-40.

Suchman, Mark. 1995. Managing Legitimacy: Strategic and Institutional Approaches. Academy of Management Review 20: 571-611. [CrossRef]

Troyer, Lisa. 2011. Legitimacy. In The Concise Encyclopedia of Sociology. Edited by George Ritzer and Michael Ryan J. West Sussex: Wiley and Blackwell.

Tuhinul, Islam, and Leon Fulcher, eds. 2016. Residential Child and Youth Care in a Developing World: Global Perspectives. CapeTown: Pretext/CYC-Net.

Ucembe, Stephen. 2013. Exploring the Nexus between Social Capital and Individual Biographies of "Care leavers" in Nairobi, Kenya: A Life Course Perspective. Unpublished Master's thesis, ISS, Hague, The Netharlands.

Ucembe, Stephen. 2015. Institutionalization of Children in Kenya: A Child Rights Perspective Does Institutionalization of Children in Kenya Neglect a Child Rights Based Approach? Available online: http:/ / www.bettercarenetwork.org/sites/default/files/Institutionalization\%20of\%20Children\%20in\% 20Kenya\%20-\%20A\%20Child\%20Rights\%20Perspective.pdf (accessed on 4 July 2017).

Ucembe, Stephen. 2016. Why Children's Homes Are a Tragedy. The Star, June 1. Available online: https:/ /www.thestar.co.ke/news/2016/06/01/why-childrens-homes-are-a-tragedy_c1361746 (accessed on 7 October 2017).

UNICEF. 2003. Africa's Orphaned Generations. New York: UNICEF, New York: UNAIDS.

UNICEF. 2006. Africa's Orphaned and Vulnerable Generations: Children Affected by AIDS. New York: UNICEF; New York: UNAIDS; New York: PEPFAR.

United Nations General Assembly. 1989. Convention on the Rights of the Child. General Assembly Resolution 44/20. Available online: https://www.ohchr.org/EN/ProfessionalInterest/Pages/CRC.aspx (accessed on 14 June 2017).

United Nations General Assembly. 2010. Guidelines for the Alternative Care of Children. General Assembly Resolution 64/142. Available online: http:/ / www.bettercarenetwork.org/sites/default/files/Guidelines\%20for\%20the\% 20Alternative\%20Care\%20of\%20Children\%20-\%20English.pdf (accessed on 9 November 2017).

Vaara, Eero, Janne Tienari, and Juha Laurila. 2006. Pulp and Paper Fiction: On the Discursive Legitimation of Global Industrial Restructuring. Organization Studies 27: 789-810. [CrossRef]

Van der Gaag, Nikki, and Cathy Nash. 1987. Images of Africa: The UK Report. Oxford: Oxfam.

Van Leeuwen, Theo, and Ruth Wodak. 1999. Legitimizing immigration control: A discourse-historical analysis. Discourse Studies 1: 83-118. [CrossRef]

Västfjäll, Daniel, Paul Slovic, Marcus Mayorga, and Ellen Peters. 2014. Compassion fade: Affect and charity are greatest for a single child in need. PLoS ONE 9: e100115.

Vidal, Pau, Imma Guixé, and Maria Sureda. 2005. How is Legitimacy Generated in NGO's? A Case Study of Catalonia. Barcelona Research Paper Collections. Observatorio del Tercer Sector, vol. 5. Available online: http: / docplayer.net/5969518-Authors-pau-vidal-pau-vidal-tercersector-org-es-immaguixe-research-team-maria-sureda-maria-sureda-tercersector-org-es.html (accessed on 11 July 2018).

Wodak, Ruth. 2002. Aspects of Critical Discourse Analysis. Zeitschrift für Angewandte Linguistik 36: 5-31.

Wu, Jianguo. 2011. Understanding Interdiscursivity: A Pragmatic Model. Journal of Cambridge Studies 6: 95-115.

(C) 2018 by the author. Licensee MDPI, Basel, Switzerland. This article is an open access article distributed under the terms and conditions of the Creative Commons Attribution (CC BY) license (http:/ / creativecommons.org/licenses/by/4.0/). 